\title{
AKUNTANSI ASET BIOLOGIS PERKEBUNAN KOPI PADA UKM BANJARNEGARA
}

\author{
Adi Wiratno \\ Universitas Jenderal Soedirman, Purwokerto \\ adiwiratno08@yahoo.com \\ I Wayan Mustika \\ Universitas Jenderal Soedirman, Purwokerto \\ Sukirman \\ Universitas Jenderal Soedirman, Purwokerto
}

Masuk : 03-09-2020, revisi : 22-09-2020 diterima untuk diterbitkan : 22-09-2020

\begin{abstract}
The purpose of this study is to explore existing conditions in Small and Medium Enterprises (SMEs) Coffee Plantation in Banjarnegara District with a phenomenological approach. The results showed that the Small and Medium Enterprises of Coffee Plantation in Banjarnegara, some did not make financial reports, only made simple notes and relied on their memory. But there are those who make financial reports but do not comply with Financial Accounting Standards, especially PSAK 69. In terms of recognition; not yet using the term 'biological assets', in terms of measurement it still uses the acquisition price and does not calculate profits and losses. Coffee Plantation SMEs in Banjarnegara have not measured their biological assets at fair value as requested by PSAK 69.
\end{abstract}

Abstrak : Tujuan penelitian ini adalah untuk mengeksplorasi existing condition pada Usaha Kecil dan Menengah (UKM) Perkebunan Kopi di Kabupaten Banjarnegara dengan pendekatan fenomenologi. Hasil penelitian menunjukkan pelaku Usaha Kecil dan Menengah Perkebunan Kopi di Banjarnegara, ada yang tidak membuat laporan keuangan, hanya membuat catatan sederhana dan mengandalkan daya ingatannya. Tetapi ada yang membuat laporan keuangan tetapi tidak sesuai dengan Standar Akuntansi Keuangan terutama PSAK 69. Dari segi pengakuan; belum menggunakan istilah 'aset biologis', dari segi pengukuran masih menggunakan harga perolehan dan tidak melakukan perhitungan keuntungan dan kerugian. UKM Perkebunan Kopi di Banjarnegara belum mengukur aset biologisnya pada nilai wajar sesuai yang diminta oleh PSAK 69.

Kata Kunci : Aset Biologis, Perkebunan Kopi, Usaha Kecil dan Menengah

\section{PENDAHULUAN}

Tanaman kopi merupakan aset utama dalam usaha perkebunan kopi. Tanaman kopi disebut aset biologis. Aset biologis adalah aset yang dimiliki oleh usaha yang bergerak dalam bidang perkebunan dan peternakan berupa hewan atau tanaman hidup. Aset biologis memiliki karakteristik yang unik yang tidak dimiliki oleh aset lain, yaitu terdapatnya proses transformasi biologis.

Pencatatan dan pelaporan akuntansi aset biologis diatur dalam standar akuntansi internasional IAS (International Accounting Standard) 41 Agriculture dan PSAK (Pernyataan Standar Akuntansi Keuangan) 69 tentang akuntansi agrikultur. IAS 41 diterbitkan oleh IASB (International Accounting Standard Board) pada tahun 2000 dan mengalami amandemen pada tahun 2013. PSAK 69 diterbitkan oleh IAI (Ikatan Akuntan Indonesia) pada tahun 2016. PSAK 69 mengacu dan mengkonvergensi ke IAS 41 yang telah diamandemen. Standar akuntansi aset 
biologis ini mengatur pengakuan, pengukuran, pengungkapan dan penyajian aset biologis dalam laporan keuangan. Berdasarkan IAS 41 dan PSAK 69, aset biologis diukur dan dilaporkan dengan nilai wajar (fair value).

Penerapan standar akuntansi PSAK 69 dan IAS 41 bagi usaha kecil dan menengah yang bergerak di bidang perkebunan akan menimbulkan kesulitan bagi pelaku UKM. Kedua standar tersebut mewajibkan pengukuran dan pelaporan aset biologis berdasarkan nilai wajar (fair value). Riset-riset terdahulu menyatakan adanya kesulitan penerapan dan kemungkinan bias dalam pengukuran fair value untuk aset biologis (Silva et al., 2015). Elad dan Herbohn (2011) menganalisis penerapan pengukuran fair value untuk aset biologis pada perusahaanperusahaan agrikultur di negara UK, Perancis dan Australia. Hasil riset mereka menunjukkan bervariasinya kriteria penilaian aset biologis berdasarkan IAS 41 untuk ketiga negara tersebut.

Di Indonesia, riset-riset terdahulu tentang akuntansi aset biologis dilakukan pada perusahaan-perusahaan agrikultur skala besar. Riset-riset terdahulu tersebut menunjukkan belum diterapkannya pengukuran berbasis nilai wajar (fair value) pada perusahaan agrikultur di Indonesia. Perusahaan agrikultur di Indonesia menggunakan basis harga perolehan (historical cost) untuk mengukur aset biologisnya. Hasil riset Sugianingtyas dan Fitriasari (2016) menunjukkan bahwa Perkebunan PT. Kusumasatria Agrobio Tani Perkasa (Kusuma Agrowisata) juga masih menerapkan harga perolehan (historical cost) untuk mengukur aset biologis tanaman apel. Selain itu, Maruli dan Mita (2010) menunjukkan bahwa perusahaanperusahaan sektor agrikultur yang terdaftar di Bursa Efek Indonesia juga masih menerapkan harga perolehan (historical cost) dan belum menerapkan nilai wajar (fair value) dalam mengukur aset biologis mereka.

Berdasarkan fenomena potensi perkembangan UKM perkebunan kopi Banjarnegara, dan adanya research gap terbatasnya riset-riset terdahulu tentang akuntansi aset biologis pada usaha kecil dan menengah, maka perlu dilakukan penelitian yang mengeksplorasi praktik pencatatan dan pengukuran aset biologis pada usaha kecil menengah perkebunan kopi di Kabupaten Banjarnegara. Hasil eksplorasi existing condition tersebut akan menjadi dasar untuk menganalisis best practice akuntansi aset biologis untuk usaha kecil dan menengah khususnya dalam sektor perkebunan kopi di Kabupaten Banjarnegara.

Permasalahan penelitian ini adalah : Bagaimana praktik saat ini (existing condition) pengukuran dan pencatatan akuntansi aset biologis pada usaha kecil dan menengah (UKM) perkebunan kopi di Kabupaten Banjarnegara.

\section{TELAAH KEPUSTAKAAN}

\section{Perlakuan Akuntansi Aset Biologis}

Menurut PSAK 69, aset biologis (biological asset) adalah hewan atau tanaman hidup yang mengalami transformasi biologis yang terdiri dari proses pertumbuhan, degenerasi, produksi, dan prokreasi yang mengakibatkan perubahan baik kualitatif maupun kuantitatif (Ikatan Akuntan Indonesia, 2016).

Argiles et al. (2012) menyatakan bahwa aset biologis memiliki karakteristik yang unik karena melakukan transformasi biologis. Perubahan baik kualitatif maupun kuantitatif dari aset biologis ini berjalan seiring dengan risiko yang melekat untuk perusahaan. Risiko itu bisa berasal adanya pergantian musim atau adanya serangan hama yang menyebabkan produktivitas aset biologis dapat menurun. Oleh karena itu terjadi keraguan apakah penggunaan biaya historis (historical cost) dapat mencerminkan nilai aset biologis sesuai dengan keadaan sebenarnya.

PSAK 69 (2016) mengatur bahwa perusahaan dapat mengakui aset biologis atau produk agrikultur ketika, dan hanya ketika: (1) Perusahaan mengendalikan aset biologis sebagai akibat dari peristiwa masa lalu; (2) Besar kemungkinan manfaat ekonomik masa depan yang terkait dengan aset biologis tersebut akan mengalir ke perusahaan; (3) Nilai wajar atau biaya perolehan aset biologis dapat diukur secara andal. Menurut PSAK 69, dalam aktivitas agrikultur, 
pengendalian dapat dibuktikan dengan, sebagai contoh, kepemilikan hukum atas ternak dan merek atau penandaan atas ternak pada saat pengakuisisian, kelahiran, atau penyapihan. Manfaat masa depan pada umumnya dinilai melalui pengukuran atribut fisik yang signifikan.

\section{Kontroversi Pengukuran Akuntansi Aset Biologis: Fair Value versus Historical Cost}

Menurut PSAK 69 dan IAS 41, aset biologis diukur pada saat pengakuan awal suatu aset dan pada setiap akhir periode pelaporan, diukur pada nilai wajar (fair value) dikurangi dengan biaya untuk menjual (cost to sell), kecuali untuk kelompok aset biologis yang nilai wajarnya tidak dapat dikukur secara andal. Untuk produk agrikultur yang dipanen dari aset biologis milik perusahaan diukur pada nilai wajar dikurangi dengan biaya untuk menjual pada titik panen. Pengukuran berbasis nilai wajar (fair value) terhadap aset biologis merefleksikan proses transformasi biologis dan kenaikan nilai dari aset biologis tersebut selama siklus produksi. Menurut Marsh dan Fischer (2013), IAS 41 merupakan suatu usaha untuk memperbaiki keterbandingan (komparabilitas) laporan keuangan perusahaan sektor pertanian. Argiles et al. (2012) menyatakan bahwa akuntansi lebih mudah diterapkan pada sektor agrikultur dengan menggunakan pengukuran berbasis nilai wajar (fair value) daripada menggunakan pengukuran historical cost. Miranda et al. (2017) juga menunjukkan hasil penelitian yang mendukung penggunaan fair value dalam penilaian aset biologis.

Pengukuran aset biologis berbasis nilai wajar ini mendapatkan kritik dari beberapa orang. Amen (2000) menyatakan bahwa seharusnya aset biologis dan produk agrikultur diukur dengan nilai wajar hanya jika terdapat pasar aktif bagi aset biologis tersebut; sedangkan jika pasar aktif tidak ada, maka sebaiknya pengukuran dilakukan berbasis historical cost. Riset-riset terdahulu menunjukkan sulitnya menerapkan pengukuran aset biologis berbasis fair value (Silva et al., 2015). Hasil penelitian Hinke dan Starova (2013) juga menyatakan bahwa terdapat skeptisisme dalam penerapan pengukuran berbasis nilai wajar (fair value) untuk perusahaan-perusahaan agrikultur di Czech Republic. Elad dan Herbohn (2011) menganalisis penerapan pengukuran fair value untuk aset biologis pada perusahaan-perusahaan agrikultur di negara UK, Perancis dan Australia. Hasil riset mereka menunjukkan bervariasinya kriteria penilaian aset biologis berdasarkan IAS 41 untuk ketiga negara tersebut.

\section{Praktik Akuntansi Aset Biologis di Indonesia}

Riset terdahulu dari tim peneliti Pinasti et al. (2017) menunjukkan bahwa praktik akuntansi aset biologis di perusahaan-perusahaan perkebunan yang terdaftar di Bursa Efek Indonesia pada tahun 2015 masih menggunakan dasar harga perolehan (historical cost) dalam pengakuan, pengukuran, dan pengungkapan. Dari segi pengakuan, seluruh perusahaan perkebunan terdaftar di Bursa Efek Indonesia belum menggunakan istilah 'aset biologis' dalam laporan keuangannya. Dari segi pengukuran, seluruh perusahaaan masih menggunakan harga perolehan sebagai dasar pengukuran pada awal periode, akhir periode, dan pengukuran keuntungan atau kerugian aset biologis dan produk agrikultur. Seluruh perusahaan belum mengukur aset biologisnya pada nilai wajar sesuai yang diminta oleh PSAK 69, karena PSAK 69 belum diberlakukan dan belum diwajibkan pada saat penelitian dilakukan. Perbandingan antara praktik akuntansi aset biologis yang dilakukan perusahaan dengan PSAK 69 menunjukkan bahwa perbedaan signifikan terletak pada dasar pengukuran aset biologis, dimana PSAK 69 mengharuskan pengukuran aset biologis pada nilai wajar, sedangkan perusahaan mengukur aset biologisnya pada harga perolehan.

Hasil riset Cahyani dan Aprilina (2014) menunjukkan bahwa Peternakan Unggul Farm Bogor menerapkan pengukuran berbasis cost untuk ternak aset biologisnya. Demikian juga hasil riset Sugianingtyas dan Fitriasari (2016) menunjukkan bahwa Perkebunan PT. Kusumasatria Agrobio Tani Perkasa (Kusuma Agrowisata) juga masih menerapkan harga perolehan (historical cost) untuk mengukur aset biologis tanaman apel. Selain itu, Maruli dan Mita (2010) menunjukkan bahwa perusahaan-perusahaan sektor agrikultur yang terdaftar di Bursa Efek Indonesia juga masih menerapkan harga perolehan (historical cost) dan belum menerapkan nilai wajar (fair value) dalam mengukur aset biologis mereka. 


\section{METODOLOGI PENELITIAN}

Pendekatan penelitian yang akan diterapkan adalah penelitian kualitatif dengan pendekatan fenomenologi. Penelitian ini akan dilaksanakan pada konteks usaha kecil dan menengah (UKM) perkebunan kopi di Kabupaten Banjarnegara.

Informan dalam penelitian ini adalah para pelaku usaha UKM Perkebunan Kopi di kecamatan-kecamatan penghasil utama kopi di Kabupaten Banjarnegara dengan metode snowball dilakukan lebih lanjut setelah diperoleh informan-informan awal.

Metode pengumpulan informasi yang digunakan adalah wawancara mendalam (in-depth interview), focus group discussion (FGD) dan observasi. Selain dengan informan utama, wawancara dan FGD juga melibatkan para konsultan pembina industri perkebunan kopi di Kabupaten Banjarnegara. Observasi juga dilakukan untuk memperoleh informasi tentang praktik pengukuran dan pencatatan akuntansi aset biologis yang saat ini sedang dilakukan.

Informasi yang diperoleh selanjutnya dianalisis dengan proses coding. Terdapat tiga tahap coding yang akan dilakukan, yaitu open coding, axial coding dan selective coding. Tematema (code) tersebut selanjutnya dianalisis hubungan dan antar-hubungannya melalui tahap axial coding. Pada tahap selective coding, ditetapkan relasi final dari tema-tema (code) yang muncul sehingga diperoleh makna dalam bentuk bagan maupun deskripsi tentang praktik dan rumusan metode pengukuran dan pencatatan akuntansi aset biologis UKM perkebunan kopi di Kabupaten Banjarnegara.

\section{ANALISIS DAN PEMBAHASAN}

Berdasarkan informasi yang diperoleh selama penelitian dari informan Perkebunan Kopi Banjarnegara diperoleh data dan dianalis sebagai berikut:

\section{A. Pengungkapan Aset Biologis}

\section{Penentuan harga pohon kopi}

Semua informan pada saat di tanya nilai tanaman kopinya tidak tahu berapa nilai pohon kopinya. "Memang bisa dinilai mas? Saya belom pernah tau loh mas." Kata Indra

\section{Sistem penghitungan untuk untung dan rugi usaha perkebunan kopi}

Para pelaku budidaya tanaman kopi di Banjarnegara tidak melakukan perhitungan untung rugi dalam usahanya, hanya perkebunannya jalan dan harta ada penambahan sudah dikatakan untung. Informan Dwi Agung mengemukakan;"Untuk selama ini sepertinya untung-untung saja mas. Saya bisa menyekolahkan anak saya buktinya, bisa kasi makan orang dirumah."

\section{Pembuat laporan keuangan}

Pelaku usaha perkebunan kopi di banjarnegara, tidak ada yang membuat sesuai dengan sistem akuntansi yang benar, hanya membuat catatan kecil dan mengandalkan ingatan pengusaha. Belum pernah juga mendapat pelatihan pencatatan akuntansi biologis. "Tidak pernah mas", kata Slamet.

\section{B. Analisa Akuntansi Biologis pada Usaha Kecil dan Menengah Perkebunan Kopi}

\section{Perlakuan Akuntansi Aset Biologis}

Menurut PSAK 69, aset biologis (biological asset) adalah hewan atau tanaman hidup yang mengalami transformasi biologis yang terdiri dari proses pertumbuhan, degenerasi, produksi, dan prokreasi yang mengakibatkan perubahan baik kualitatif maupun kuantitatif (Ikatan Akuntan Indonesia, 2016).

Perkebunan kopi di Banjarnegara tidak melakukan bahkan tidak mengerti perlakuan akuntansi untuk aset biologis baik dari segi pengakuan (recognition), pengukuran (measurement), pengungkapan (disclosure), dan penyajian (presentation). Hal ini menjadi perhatian karena sebenarnya pelaku budidaya kopi membutuhkan pengetahuan tentang standar khusus yang mengatur tentang aset biologis, melihat banyaknya perusahaan-perusahaan baik perusahaan besar maupun UKM (usaha kecil dan menengah) yang bergerak di sektor perkebunan. Oleh karena itu terjadi ketidaktahuan 
apakah penggunaan biaya historis (historical cost) dapat mencerminkan nilai aset biologis sesuai dengan keadaan sebenarnya. Penggunaan biaya historis hanya mempertimbangkan harga perolehan awal dari aset biologis tanpa memperhatikan adanya perubahan-perubahan atau risiko yang dapat merubah nilai aset biologis suatu perusahaan dalam jangka waktu tertentu.

Pengukuran aset biologis berbasis nilai wajar ini mendapatkan kritik dari beberapa orang. Amen (2000) menyatakan bahwa seharusnya aset biologis dan produk agrikultur diukur dengan nilai wajar hanya jika terdapat pasar aktif bagi aset biologis tersebut; sedangkan jika pasar aktif tidak ada, maka sebaiknya pengukuran dilakukan berbasis historical cost. Riset-riset terdahulu menunjukkan sulitnya menerapkan pengukuran aset biologis berbasis fair value (Silva et al.). Hasil penelitian Hinke dan Starova (2013) juga menyatakan bahwa terdapat skeptisisme dalam penerapan pengukuran berbasis nilai wajar (fair value) untuk perusahaan-perusahaan agrikultur di Czech Republic. GregeStaltmane (2010) menyatakan banyak penyesuaian yang harus dilakukan untuk menerapkan IAS 41 dalam perlakuan akuntansi perusahaan sektor kehutanan di Latvia. Elad dan Herbohn (2011) menganalisis penerapan pengukuran fair value untuk aset biologis pada perusahaan-perusahaan agrikultur di negara UK, Perancis dan Australia. Hasil riset mereka menunjukkan bervariasinya kriteria penilaian aset biologis berdasarkan IAS 41 untuk ketiga negara tersebut. Silva et al. (2012) juga menyatakan bahwa adopsi fair value untuk mengukur aset biologis perusahaan-perusahaan agrikultur di Brasil menimbulkan kesulitan tersendiri. Chalomklang (2012) menunjukkan hasil penelitian bahwa nilai yang reliable dalam pengukuran nilai wajar sulit ditemukan. Hasil riset Oliveira et al. (2015) juga menunjukkan ketidakkonsistenan dalam penerapan nilai pasar untuk aset biologis. Khoruzhiy dan Deitch (2015) mengusulkan perlunya pengembangan lebih lanjut dari pengukuran aset biologis berbasis nilai wajar (fair value).

\section{Praktik Akuntansi Aset Biologis di UKM Banjarnegara}

Dari informasi informan yang diperoleh, sebagian besar pelaku Usaha Kecil dan Menengah Perkebunan Kopi di Banjarnegara tidak membuat laporan keuangan hanya membuat catatan sederhana dan mengandalkan daya ingatannya. Sebagian kecil membuat laporan keuangan tetapi tidak sesuai dengan standar akuntansi keuangan terutama PSAK 69. Riset terdahulu dari tim peneliti Pinasti et al. (2017) menunjukkan bahwa praktik akuntansi aset biologis di perusahaan-perusahaan perkebunan yang terdaftar di Bursa Efek Indonesia pada tahun 2015 masih menggunakan dasar harga perolehan (historical cost) dalam pengakuan, pengukuran, dan pengungkapan.

Dari segi pengakuan, perkebunan kopi di Banjarnegara belum menggunakan istilah 'aset biologis' dalam catatan laporan keuangan sederhana yang dimiliki. Dari segi pengukuran, UKM perkebunan kopi di banjarnegara masih menggunakan harga perolehan sebagai dasar pengukuran pada awal periode, akhir periode, dan pengukuran keuntungan atau kerugian aset biologis tidak dilakukan karena ketidaktahuannya. UKM Perkebunan Kopi di Banjarnegara belum mengukur aset biologisnya pada nilai wajar sesuai yang diminta oleh PSAK 69.

Perbandingan antara praktik akuntansi aset biologis yang dilakukan perusahaan dengan PSAK 69 menunjukkan bahwa perbedaan signifikan terletak pada dasar pengukuran aset biologis, dimana PSAK 69 mengharuskan pengukuran aset biologis pada nilai wajar, sedangkan perusahaan mengukur aset biologisnya pada harga perolehan.

\section{KESIMPULAN DAN SARAN}

Pelaku UKM Perkebunan Kopi di Banjarnegara secara umum tidak tahu atau tidak menguasi Akuntansi Aset Biologis. UKM Perkebunan Kopi di Banjarnegara tidak membuat 
Laporan Keuangan Usaha Perkebunan Kopinya, yang dibuat hanya catatan sederhana yang tidak sesuai dengan PSAK 69. Saran yang diberikan penulis adalah perlu adanya sosialisasi Akuntansi Aset Biologis dan pembuatan laporan keuangan agribisnis.

\section{DAFTAR PUSTAKA}

Amen, M. (2000). Comment Letter on Exposure Draft E65 - Agriculture No. 13. [online] Available on http://media.ifrs.org/CommentsE65.zip.cit.20110512.

Argiles, J.M., Sabata, A., \& Garcia-Blandon, J. (2012). A Comparative Study of Difficulties in Accounting Preparation and Judgement in Agriculture Using Fair Value and Historical Cost for Biological Assets Valuation. RC-SAR, 5 (1), 109 - 142.

Cahyani, R.C., Aprilina, V. (2014). Evaluasi Penerapan SAK ETAP dalam Pelaporan Aset Biologis pada Peternakan Unggul Farm Bogor. JRAK, 5 (1), 14-37.

Chalomklang, C. (2012). Impact and a Guideline for Accounting Practice in Accordance with the Agricultural Accounting Standard of Agricultural Business of Thailand. International Journal of Arts \& Sciences, 5 (1), 251-256.

Elad, C., Herbohn, K. (2011). Implementing Fair Value Accounting in the Agricultural Sector. The Institute of Chartered Accountants of Scotland, London.

Grege-Staltmane, E. (2010). Challenges in Accounting the Forests - a Latvian Case Study. Annals of Forest Research, 53 (1), 51-58.

Hinke, J., Starova, M. (2013). Application Possibilities and Consequences of Biological Assets and Agricultural Produce Reporting in Accordance with IFRS Principles in the Czech Republic. Agris on-line Papers in Economics and Informatics, V (4), 77-89.

Ikatan Akuntan Indonesia. (2016). Pernyataan Standar Akuntansi Keuangan 69 tentang Akuntansi Agrikultur. Ikatan Akuntan Indonesia. Jakarta, Indonesia.

International Accounting Standards Board (IASB). (2013). International Accounting Standard (IAS) 41 Agriculture. IASB. London, UK.

Khoruzhiy, L.I., Deitch, U. (2015). Development of Account and Financial Statement Report Methods of Operations Formulating Economic Result from Biotransformation of Poultry Biological Assets. Accounting in Agriculture, 12, 7 - 17.

Marsh, T., Fischer, M. (2013). Accounting for Agricultural Products: US versus IFRS GAAP. Journal of Business \& Economics Research, 11 (2), 79-88.

Maruli, S., Mita, A.F. (2010). Analisis Pendekatan Nilai Wajar dan Nilai Historis dalam Penilaian Aset Biologis pada Perusahaan Agrikultur: Tinjauan Kritis Rencana Adopsi IAS 41. Prosiding Simposium Nasional Akuntansi XIII. Ikatan Akuntan Indonesia.

Miranda, H.D., Mojica, L.E., Madamba, J.A.B., Zapata, N.R. (2017). Accounting Practices and International Accounting Standard (IAS)/Philippine Accounting Standard (PAS) 41 Compliance of Cattle Farms: Evidence from the Philippines. The Journal of Global Business and Trade, 13 (1), 55-77.

Oliveira, J.S., Azevedo, G.M.C., Santos, C.S.A., Vasconcelos, S.C.S. (2015). Fair Value: Model Proposal for the Dairy Sector. Agricultural Finance Review, 75 (2), 230-252.

Pinasti, M., Mustika, I.W., Wiratno, A., Prijono, A.K. (2017). Portrait of Accounting for Biological Assets of Agricultural Company in Indonesia. Proceeding The $4^{\text {th }}$ Sebelas Maret International Conference on Business, Economics and Social Sciences 2017.

Silva, R.L.M., Nardi, P.C.C., Ribeiro, M.S. (2015). Earnings Management and Valuation of Biological Assets. Brazilian Business Review, 12 (4), 1 - 26.

Sugianingtyas, E.H., Fitriasari, R. (2016). Perlakuan Akuntansi Aset Biologis Tanaman Apel pada Perkebunan PT Kusumasatria Agrobio Tani Perkasa (Kusuma Agrowisata) Sesuai IAS 41 Agriculture. Jurnal Ilmiah Mahasiswa FEB Universitas Brawijaya, 4 (2). 